Environment Conservation Journal 15(1\&2)225-228, 2014

ISSN 0972-3099 (Print) 2278-5124 (Online)

Abstracted and Indexed

\title{
Seasonal trends in physico-chemical parameters and zooplankton in a freshwater reservoir of Dejla Dewada, Khargone, M.P.
}

\author{
S. K. Pathak and Sandhya Kshetrey $₫$
}

Received:16.10.2013

Revised:05.01.2014

Accepted:05.03.2014

\begin{abstract}
Seasonal variation in physico-chemical and zooplankton communities of Dejla Dewada Reservoir (D.D.R.), West Nimar district (Khargone) was studied during October 2009 to September 2010. Protozoa, Rotifera, Copepoda, Cladocera and Ostrcoda were found dominated zooplanktonic groups. The total zooplankton density ranged between 879 unit/L to 2980 unit/L.The composition of zooplankton was found as Protozoa >Rotifera>Copepoda>Cladocera>Ostracoda.
\end{abstract}

Keywords: Dejla Dewada Reservoir, physico-chemical parameters, zooplankton

\section{Introduction}

Limnologists have been examining and describing the pattern of several successions of zooplankton species, since the turn of the century (Hutchinson, 1967). The phagotrophs and saprophytes composed mostly zooplankton, micro-invertebrates and fishes etc. The aquatic ecosystems have a great diversity in their form, distribution, adaptation and seasonal variation. The zooplanktonic population serves as natural food for macro-invertebrates, culturable fishes and aquatic birds. The zooplankton form a major link in the energy transfer at secondary level in aquatic biotops. They occupy an intermediate position in the food webs between autotrophs and heterotrophs. The distribution and diversity of zooplankton in aquatic ecosystems depend mainly on the physicochemical properties of water. The several zooplankton species have been classified as indicator of polluted conditions. The present paper deals with the Seasonal trends in physico-chemical parameters and zooplankton in a freshwater reservoir of Dejla Dewada, Khargone, M.P.

\section{Material and Methods}

The Dejla Dewada Reservoir, of West Nimar district (Khargone) is irrigation water body having a length of about 1640 meters with a catchment area of about $335.40 \mathrm{Sq}$. Km. The gross storage capacity is about $56.35 \mathrm{M}$ cum. The Dejla Dewada Author's Address

P.G.Department of Zoology, B.L.P.Govt.P.G.College, Mhow (M.P.)

Email: skpathak57@gmail.com reservoir (Fig.1) is situated on the river Kunda, a tributary of Narmada basin near village Bhagwanpura (about $35 \mathrm{Kms}$ away from the district head quarter of West Nima). Geographically location this reservoir located at latitude 21036'45"and longitude 750-37'-30". This water body was constructed in 1986-87 with the help of World Bank. It is situated 369.56 meter above the mean sea level. The Physico-chemical parameters such as water temperature, $\mathrm{pH}$, free $\mathrm{CO}_{2}$, dissolved oxygen, chloride, total alkalinity, total hardness, potassium, sulphate were estimated according to APHA (1989), Khanna and Bhutiani (2008) and Chattopadhyay,(1998). For estimation of zooplankton the samples were collected at monthly interval by filtering 50 litres of water through plankton net made up of bolting silk cloth no. 20.The samples were preserved in 5\% formalin solution and stored in $50 \mathrm{ml}$. glass vials .The qualitative and quantitative enumeration of zooplankton was made according to Tonapi, (1960), Needham \& Needham (1962) and Pennak (1972).

\section{Results and Discussion}

The results of various Physico-chemical parameters obtained during course of study are presented in table-1. In the present study temperature fluctuated between $17.6^{\circ} \mathrm{C}$ (December, 2009) and $29.7^{\circ} \mathrm{C}$ (June, 2010). The fluctuation of temperature was well within the limit for survival of fishes. 


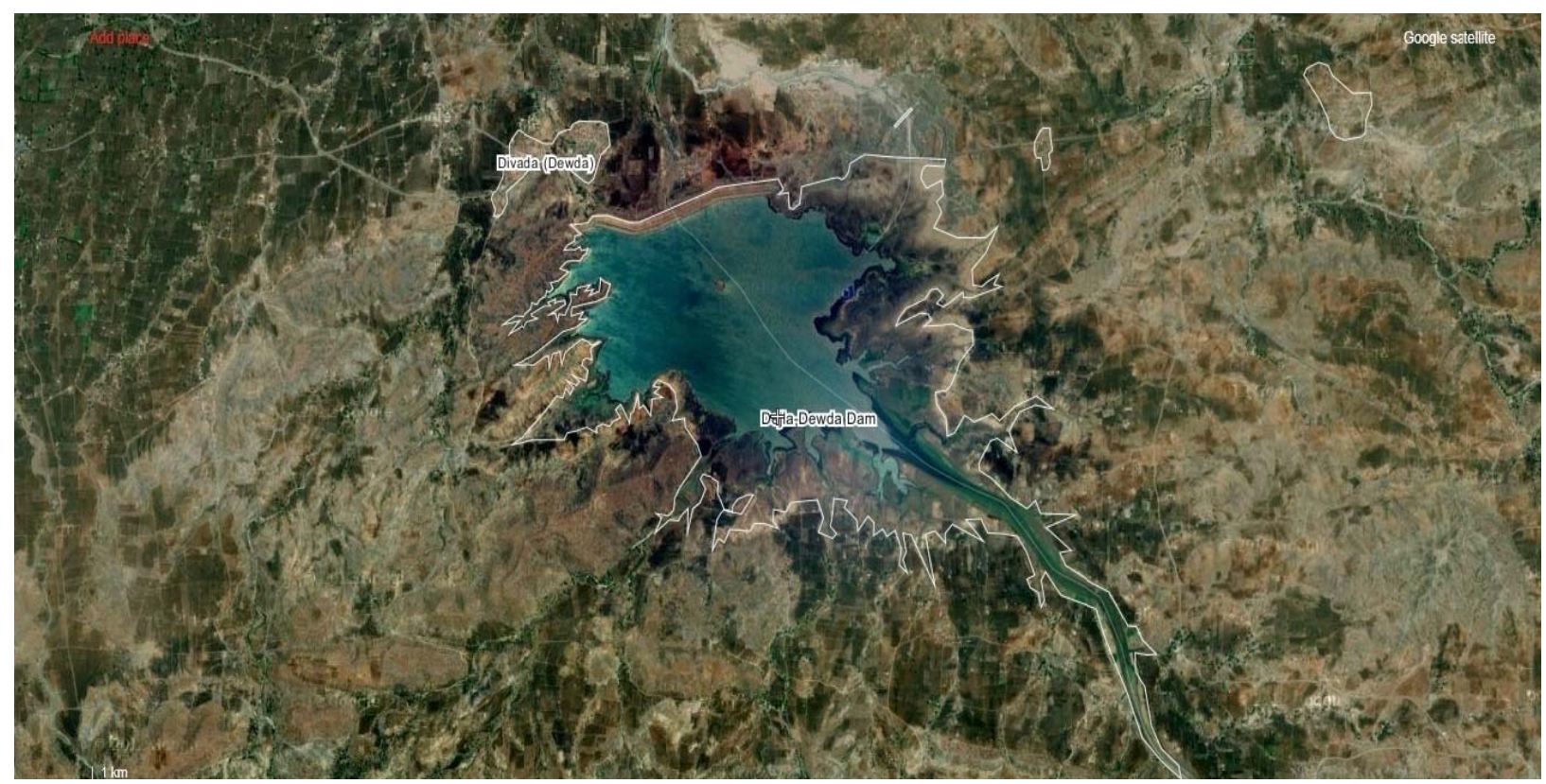

Fig.1- Satellite View of Dejla Dewada Reservoir

Table 1 - Showing monthly variations in physico-chemical parameters in Dejla Dewada reservoir

\begin{tabular}{|l|l|l|l|l|l|l|l|l|l|}
\hline Months/Year & $\begin{array}{l}\text { Water } \\
\text { Temp. } \\
(\mathbf{(} \mathbf{C})\end{array}$ & $\mathbf{p H}$ & $\begin{array}{l}\text { Free } \\
\mathbf{C o}_{\mathbf{2}} \\
\mathbf{( m g / l )}\end{array}$ & $\begin{array}{l}\text { DO } \\
\mathbf{( m g / l )}\end{array}$ & $\begin{array}{l}\text { Chloride } \\
\mathbf{( m g / l )}\end{array}$ & $\begin{array}{l}\text { Total } \\
\text { alkalinity } \\
(\mathbf{m g} / \mathbf{l})\end{array}$ & $\begin{array}{l}\text { Total } \\
\text { hardness } \\
\mathbf{( m g / l )}\end{array}$ & $\begin{array}{l}\text { Potassium } \\
\mathbf{( m g / l )}\end{array}$ & $\begin{array}{l}\text { Sulphate } \\
(\mathbf{m g} / \mathbf{l})\end{array}$ \\
\hline October 09 & 27.9 & 8.25 & 2.26 & 6.15 & 18.67 & 127.37 & 123.85 & 1.25 & 22.11 \\
\hline November 09 & 21.5 & 8.23 & 1.28 & 8.35 & 16.81 & 133.50 & 119.62 & 1.22 & 20.65 \\
\hline December 09 & 17.6 & 8.23 & 1.78 & 8.91 & 17.25 & 141.82 & 120.91 & 1.19 & 15.12 \\
\hline January 10 & 19.4 & 8.21 & 1.39 & 8.12 & 19.31 & 134.55 & 121.47 & 1.15 & 16.07 \\
\hline February 10 & 22.4 & 8.22 & 1.64 & 7.61 & 21.77 & 108.60 & 123.21 & 1.17 & 18.21 \\
\hline March 10 & 25.8 & 8.24 & 2.25 & 6.71 & 24.45 & 107.65 & 126.47 & 1.19 & 19.95 \\
\hline April 10 & 28.3 & 8.27 & 2.76 & 5.57 & 26.76 & 127.87 & 134.01 & 1.21 & 21.07 \\
\hline May 10 & 29.6 & 8.31 & 3.24 & 5.12 & 28.37 & 142.75 & 144.51 & 1.25 & 26.52 \\
\hline June 10 & 29.7 & 8.28 & 2.61 & 5.37 & 31.94 & 135.85 & 153.21 & 1.27 & 31.57 \\
\hline July 10 & 29.6 & 7.87 & 2.46 & 5.51 & 25.15 & 113.22 & 104.21 & 1.01 & 33.95 \\
\hline August 10 & 27.5 & 7.79 & 2.59 & 5.52 & 22.12 & 109.47 & 96.32 & 0.98 & 29.75 \\
\hline September 10 & 28.8 & 8.17 & 2.05 & 6.12 & 20.47 & 105.27 & 92.95 & 1.21 & 24.77 \\
\hline
\end{tabular}

Similar types of fluctuations were reported by maximum oxygen during winter season, which may Dwivedi et al. (1995) in two ponds at Patna. A be due to higher photosynthesis rate and dissolution more or less similar trend has been observed in the of oxygen during winter season as suggested by river Yamuna by Chakrabarty et al. (1959) and in Hutchinson (1967). Similar trend of D.O. was also the Kallayi (John, 1976). Badola and Singh (1981) observed by Badola and Singh (1981) for river reported similar trend in river Alaknanda. pH Alaknanda, Khanna et al. (2009) and Chugh (2000) represent the intensity of acidity or alkalinity of for the river Ganga. The free $\mathrm{CO}_{2}$ ranged from water. It plays a limiting role in the growth of flora $1.28 \mathrm{mg} / \mathrm{l}$ to $3.24 \mathrm{mg} / \mathrm{l}$. The presence of free $\mathrm{CO}_{2}$ and fauna of aquatic body.The $\mathrm{pH}$ of Delja Dewda was may be due to more aquatic vegetation in the Reservoir was on alkaline scale ( $\mathrm{pH} 7.79$ to 8.31) reservoir. However, it was found low in all seasons. with irregular trend of seasonal fluctuation.The An inverse relationship between free $\mathrm{CO}_{2}$ and $\mathrm{pH}$ D.O. ranged from $5.12 \mathrm{mg} / \mathrm{l}$ to $8.9 \mathrm{mg} / \mathrm{l}$ with was observed by Singhal et al. (1985). The 
chlorides ranged between 16.81 to $31.94 \mathrm{mg} / \mathrm{l}$ with narrow range of seasonal variation. The total alkalinity values in the D.D.R.was also fluctuated in a narrow range with minimum value of 105.27 $\mathrm{mg} / \mathrm{l}$ and maximum value of $142.75 \mathrm{mg} / \mathrm{l}$. This observation is similar to the findings of Venkateshwarlu and Jayanti (1968) for the river Sabarmati, Khanna et al. (2009) found similar trend in river Yamuna. The value of total hardness is governed by the contents ofcalcium and magnesium salts, largely combined with bicarbonate, carbonate, sulphate and chloride.The total hardness ranged from $92.95 \mathrm{mg} / \mathrm{l}$ to $153.21 \mathrm{mg} / \mathrm{l}$.The sulphate was observed fluctuating throughout the year. However, it was found higher in summer season (33.95 $\mathrm{mg} / \mathrm{l}$ ).During the present investigation the minimum $(0.98 \mathrm{mg} / \mathrm{l})$ potassium content was recorded in the month of August 2010 and maximum $(1.27 \mathrm{mg} / \mathrm{l})$ in the month of June 2010. During the course of study the zooplankton population was represented by five groups viz. Protozoa, Rotifera, Copepoda, Cladocera and Ostrcoda. A total of 20 zooplankton genera were identified, out of which 6 genera belong to each Protozoa and Rotifera, 3 genera to each Cladocera and Copepoda and 2 genera to Ostracoda. The Protozoa genera recorded were Arcella, Amoeba, Vorticella, Volvox, Euglena and Paramecium. Rotifera genera observed were Keratella, Philodima, Notholca, Elosa, Filina and Mytilina. In Cladocera genera observed were Daphnia, Bosmina and Alona. Copepoda includes genera Cyclops, Diaptomus and Eucyclops and Ostracoda genera Cypris and Candona. Table 2 - represents monthly density and percentage composition (\%) of various zooplanktonic groups in Dejla Dewada Reservoir.

The total zooplankton density of Delja Dewda Reservoir ranged from 879 unit/ L in August, 2010 to 2980 unit $/ \mathrm{L}$ in November 2009. Among the zooplankton, Protozoa and Rotifera were most dominant groups (Table-3). The Cladocera and Copepoda were found to be the second most dominant group. The Ostracoda was the least dominant group and their percentage composition ranged between $7.71 \%$ to $12.97 \%$.

Table 2: Showing Monthly density and percentage composition (\%) of various zooplanktonic groups in Dejla Dewada Reservoir

\begin{tabular}{|c|c|c|c|c|c|c|c|c|c|}
\hline $\begin{array}{c}\text { Months } \\
\text { /Year }\end{array}$ & $\begin{array}{c}\text { Water } \\
\text { Temp. } \\
\left({ }^{0} \mathrm{C}\right)\end{array}$ & $\mathbf{p H}$ & $\begin{array}{c}\text { Free } \\
\mathrm{CO}_{2} \\
(\mathrm{mg} / \mathrm{l})\end{array}$ & $\begin{array}{c}\text { DO } \\
(\mathrm{mg} / \mathrm{l})\end{array}$ & $\begin{array}{c}\text { Chloride } \\
\text { (mg/l) }\end{array}$ & $\begin{array}{c}\text { Total } \\
\text { alkalinity } \\
\text { (mg/l) }\end{array}$ & $\begin{array}{c}\text { Total } \\
\text { hardness } \\
(\mathbf{m g} / \mathbf{l})\end{array}$ & $\begin{array}{c}\text { Potassium } \\
\text { (mg/l) }\end{array}$ & $\begin{array}{c}\text { Sulphate } \\
\text { (mg/l) }\end{array}$ \\
\hline October 09 & 27.9 & 8.25 & 2.26 & 6.15 & 18.67 & 127.37 & 123.85 & 1.25 & 22.11 \\
\hline November 09 & 21.5 & 8.23 & 1.28 & 8.35 & 16.81 & 133.50 & 119.62 & 1.22 & 20.65 \\
\hline December 09 & 17.6 & 8.23 & 1.78 & 8.91 & 17.25 & 141.82 & 120.91 & 1.19 & 15.12 \\
\hline January 10 & 19.4 & 8.21 & 1.39 & 8.12 & 19.31 & 134.55 & 121.47 & 1.15 & 16.07 \\
\hline February 10 & 22.4 & 8.22 & 1.64 & 7.61 & 21.77 & 108.60 & 123.21 & 1.17 & 18.21 \\
\hline March 10 & 25.8 & 8.24 & 2.25 & 6.71 & 24.45 & 107.65 & 126.47 & 1.19 & 19.95 \\
\hline April 10 & 28.3 & 8.27 & 2.76 & 5.57 & 26.76 & 127.87 & 134.01 & 1.21 & 21.07 \\
\hline May 10 & 29.6 & 8.31 & 3.24 & 5.12 & 28.37 & 142.75 & 144.51 & 1.25 & 26.52 \\
\hline June 10 & 29.7 & 8.28 & 2.61 & 5.37 & 31.94 & 135.85 & 153.21 & 1.27 & 31.57 \\
\hline July 10 & 29.6 & 7.87 & 2.46 & 5.51 & 25.15 & 113.22 & 104.21 & 1.01 & 33.95 \\
\hline August 10 & 27.5 & 7.79 & 2.59 & 5.52 & 22.12 & 109.47 & 96.32 & 0.98 & 29.75 \\
\hline September 10 & 28.8 & 8.17 & 2.05 & 6.12 & 20.47 & 105.27 & 92.95 & 1.21 & 24.77 \\
\hline
\end{tabular}

Table 3 - Percentage composition of zooplankton

\begin{tabular}{|l|l|l|l|l|l|}
\hline Group & Protozoa & Rotifera & Cladocera & Copepoda & Ostracoda \\
\hline $\begin{array}{l}\text { Percentage } \\
\text { composition }\end{array}$ & $22.53-36.69$ & $21.77-33.24$ & $11.72-18.22$ & $12.16-18.57$ & $7.71-12.97$ \\
\hline
\end{tabular}




\section{References}

APHA, AWWA and WPCF. 1989. Standard Methods for the Examination of Water and Waste Water. $17^{\text {th }}$ edition, APHA,Inc. New York. P.1268.

Badola, S.P. and Singh, H.R. 1981. Hydrobiology of the river Alaknanda of Garhwal Himalaya. Indian J. Ecol., 8(2): 269276.

Chattopadhyay, G.N. 1998.Chemical analysis of fish pond soil and water: Daya publishing house Delhi.

Chugh, Tarun, 2000. Seasonal variation in the microbial ecology of river Ganga at Hardwar, Ph.D. thesis, Gurukul Kangri University Hardwar.

Dwivedi, H.N., Pandey, B.N., Manoj, Kumar and Naushad Alam, 1995. Limnological studies in relation to fish production of two ponds of Patana. Him. J. Env-Zoo., 9: 710.

Hutchinson, G.E. 1967. A Treatise on Limnology: 2.Wiley Inter Science, New York, 1015.

John, V. 1976. Hydrobiological studies of the river Kallayi in Kerala. Indian J. Fish, 23: 72-85.

Khanna, D.R. and Bhutiani, R. 2008. Laboratory manual for water and waste water analysis. Daya publishing house, New Delhi
Khanna, D.R., Bhutiani, R. , Gagan, Matta , Dheeraj, Kumar, Singh, V. and Ashraf, J. 2009. A study of Zooplankton diversity with special reference to their concentration in river Ganga at Haridwar. Env.Con.J..Vol 10(3):15-20.

Khana D.R., Bhutiani, R. Gagan Matta, Vikas singh and Fouzia Ishaq 2012. Seasonal variation in physico-chemical characteristic status of River Yamuna in Doon Valley of Uttarakhand. Env. Con. J. 13(1\&2): 119-124.

Needham, J.G. and Needham, P.K. 1962. A guide to the study of fresh water Biology Holden-Day Inc. Sanfrancisco 108.

Pennak, R.W. 1978. Freshwater invertebrates of united states. Ronald Press. Co. New York. 769 pp.

Singhal, R.N., Jeet,S. and Davis,R.W.1985.The relationship among physical,chemical and plankton characteristics of unregulated rural ponds in Haryana,India.Trop.Ecol.26:4353.

Tonapi, G.T. 1960.Freshwater animals of India: An ecological approach.Oxford and IBH,New Delhi,India.

Venkateshwarlu, T. and Jayanti, T.V., 1968. Hydrobiological studies of the river Sabarmati to evaluate water quality. Hydrobiologia, 33(3-4): 442- 448. 